\title{
Hybrid Solar-Wind Installation Prospects for Hot Water and Heating Supply of Private Homes on the Apsheron Peninsula of the Republic of Azerbaijan
}

\author{
Arzu Huseynov ${ }^{1}$, EInur Abbasov ${ }^{1}$, Oktay Salamov $^{2}$, and Firuze Salmanova ${ }^{2}$ \\ IInstitute of Environmental Engineering, Kaunas University of Technology, Kaunas, Lithuania \\ ${ }^{2}$ Institute of Radiation Problems of Azerbaijan National Academy of Sciences, Baku, Azerbaijan \\ Corresponding author: \\ Abbasov, E., Institute of Environmental Engineering, Kaunas University of Technology, K. Donelaičio St. 20, \\ Kaunas, Lithuania \\ E-mail: abbasov.lnr@gmail.com
}

(received in May 2015; accepted in July 2015)

\begin{abstract}
This paper analyses the environmental problems arising from the use of traditional energy resources for the production of electricity and heat. The advantages of replacing conventional energy resources and shifting to wind and solar energy technologies are explained. The possibilities of the combined use of solar and wind energy to provide an average family of 5 people with hot water and heating are explored. Experimental results were obtained from full-scale tests under prevailing conditions at Baku. Solar-wind hybrid systems for heating and hot water were designed and developed at the Institute of Radiation Problems of the Azerbaijan National Academy of Sciences. The paper also examines the possibility of supplying a family of 5 people with hot water produced by solar energy year-round and presents the results of the calculation of the energy balance of such facility.
\end{abstract} tank.

Keywords: flat-plate solar collectors, wind turbine, hybrid solar-wind installation, cold water

\section{Introduction}

In recent years, environmental conditions have become much worse as a result of technogenic and anthropogenic processes taking place in the world. Literature sources indicate that since the 1980s flatplate solar collectors (FSC) have been used to supply heating (HS) and hot water (HWS) (Kharchenko, 1991; Bekman et al., 1982; Salamov et al., 2006; Carbonell et al., 2014; NREL, 2012; Sun \& Wind Energy, 2014). However, the dependence of solar radiation intensity on arbitrary changes over time, in particular the stochastic nature of this change, causes interruptions in heat and hot water supplies in differing weather conditions. One way to resolve this situation is to use very large surface area flat-plate solar collectors. Another option is to install additional equipment for the accumulation of solar radiation. Neither strategy is economically ideal. Thus, a continuous and reliable way of providing energy to consumers through the use of large surface flat-plated solar collectors in winter is not productive in spring and summers seasons, because only $10-15 \%$ of the thermal energy produced is used in place while the rest, which could be converted into other energy forms, is lost in an inefficient manner. In this case, FSCs are operating at a very critical temperature, which is harmful for inner pipes of collectors and can result in premature failure. On the other hand, the surface of a needed FSC being 5 to 6 times more than the normal size can increase costs in the same way (Salamov et al., 2006). Heat accumulative systems can be productive only in the daily and monthly provision of heat and hot water supplies, which cannot be applied for seasonal demand, and this again leads to an increase in the unit cost (Polyanin, 1998; Abdelmoneym, 1998). Thus, to provide consumers with a continuous hot water supply all year round and to ensure a sustainable heating season, solar thermal power plants are used in combination with alternative 
energy sources (Ushakova, 1986; Shershnev, Dudarev, 2006; Sun \& Wind Energy, 2014). To this end, private residential homes with natural gas use electrically-powered heating devices, and social order houses use diesel-fuelled power generators. However, in these cases, either directly (in private homes) or indirectly (thermal power plants), the use of existing resources from traditional fuel cannot be considered effective from an economic and environmental point of view. The use of wind power as a heating supply has been discussed since the 1990s; however, it is considered ineffective from an economical and ecological point of view. That is why from the beginning of this century the combined use of solar and wind energy started to become more and more important. The issue of special significance solar-wind combined installations for the production of heating and hot water supplies has become an important topic for the 'Transformation of Renewable Energy Types' Laboratory of the Institute of Radiation Problems of the Azerbaijan National Academy of Sciences since the beginning of the $21^{\text {st }}$ century as well, and successful results have been obtained. The results have been published in the periodical press from time to time (Salamov et al., 2006, 2009, 2010).

Given these premises, a combined solar and wind power installation (CSWPI) experimental model was designed and created by the 'Transformation of Renewable Energy Types' Laboratory of the Institute of Radiation Problems of the Azerbaijan National Sciences Academy. This experimental model was tested under the natural climatic conditions occurring on the Apsheron Peninsula. Below is a description of the device, its working principles, the results of the calculation and the testing of the device for supplying heating and hot water to consumers. One of the main objectives of the study is to prepare long-term strategies for high demand consumers such as schools, kindergartens, hospitals, sanatoriums, public catering facilities, factories outside the city, difficult to access strategically important locations, military installations, all based on the experience gained from the usage of the CSWPI on the Apsheron Peninsula.

Azerbaijan is one of the leading countries in the world with regard to solar and wind energy reserves. It has been determined that the Apsheron Peninsula, which is located at $40^{\circ} 24^{\prime}$ latitude, and Baku City have 300 sunny days during a year, receiving nearly 3000 annual hours of sunshine. The average solar radiation energy reaching every $1 \mathrm{~m}^{2}$ of the horizontal surface is $1900 \mathrm{~W} / \mathrm{m}^{2}$ per year, the maximum rating of solar radiation intensity during each day is $950 \mathrm{~W} / \mathrm{m}^{2}$, and the average annual rating of the same index is near 200 $\mathrm{W} / \mathrm{m}^{2}$. The ratings for working hours in winter and summer seasons are 4.8-7.8 and 7.2-12.5 hours, respectively (Salamov et al., 2013).

When it comes to the wind regime, the amount of windy days during a year on the Apsheron Peninsula and Caspian coastlines is 270-280 days, the average annual wind speed is $7-8 \mathrm{~m} / \mathrm{s}$ at a height of $12 \mathrm{~m}$, but in some places it is more than $10 \mathrm{~m} / \mathrm{s}$. All these show that the Apsheron Peninsula has significant wind potential (Salamov et al., 2010; Hashimov et al., 2012)

As can be seen, the use of ecologically clean and inexhaustible solar and wind energy to provide for the hot water and heating demands of homes has an exceptional significance on the Azerbaijani area, especially in the climatic conditions present on the Apsheron Peninsula and Baku City. For this reason, combined solar and wind energy facilities could provide consumers with more sustainable and continuous thermal energy.

\section{Materials and methods}

\subsection{Schematic structure of experimental CSWPI}

It is commonly known that the energy needs of consumers for hot water and heating can currently be satisfied by flat-plate solar collectors (FSC) and pipelike collectors that utilise solar radiation and do not require monitoring systems when operated. Along with their simple structure, another advantage of FSCs is their low cost. They allow for maximal utilisation of solar energy due to their capacity to run within a wide range of solar radiation intensity (SRI) values (Kharchenko, 1991; Panjiyev, 2007). However, studies show that a family composed of 5 members may not have a guaranteed hot water supply in winter, not to mention a supply of heating energy (Salamov et al., 2006). Under the Baku City's climatic conditions, such families will need an FSC with an overall surface area of 9-12 $\mathrm{m}^{2}$ for a reliable hot water supply, while reliable heating energy will require a much larger surface area, exceeding $50 \mathrm{~m}^{2}$. First of all, this is not an economically feasible option. Besides, such a large surface area makes the natural circulation of a heat transfer agent impossible due to the fact that connecting several FSCs in a series increases the pressure within the circulation circuit. This results in force-feed circulation, which requires operation of a circulating pump. In addition, it becomes necessary to provide automatic regulation for heat transfer agent consumption in accordance with daily fluctuations in SRI values. Such additional interventions greatly complicate the installation's structural design and reduce the consumer's interest in its utilisation. Therefore, individual households should be provided with additional energy resources for a heating power supply during heating seasons in addition to a yearround hot water supply. It has been established that wind turbines may serve as such an additional source, while their use in combination with FSCs is of even greater interest (Salamov \& Salmanova 2010; Salamov et al., 2013).

Given the above-mentioned premises, a combined solar and wind power installation experimental model was designed and created by the 'Transformation of Renewable Energy Types' Laboratory of the Institute of Radiation Problems of the Azerbaijan National Sciences Academy. This experimental model was tested under natural climatic conditions on Apsheron Peninsula. The following text provides a description of the device, the principles 
behind its operation, and the results of calculations for testing the device, which would be providing heating and hot water supplies to consumers.

Figure 1 and Figure 2 show the general appearance of the CSWPI and its simplified electric circuit diagram, respectively.

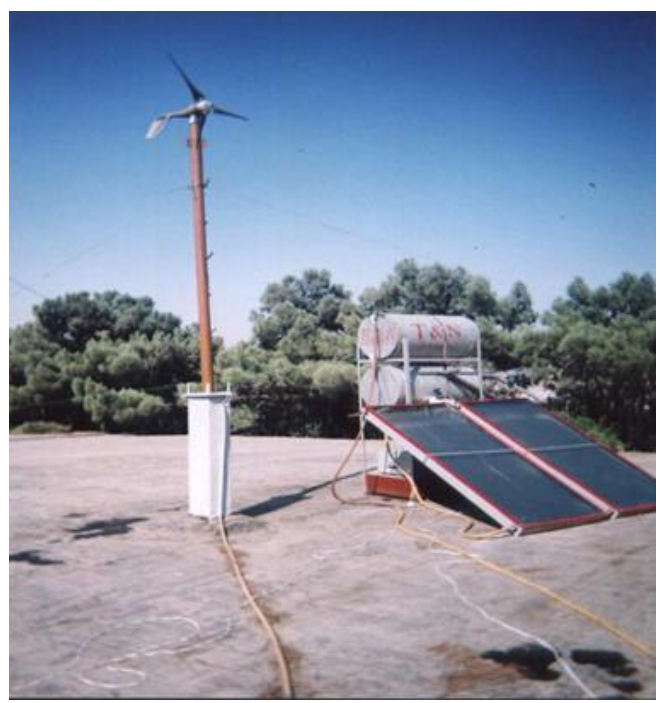

Figure 1. General appearance of the CSWPI.

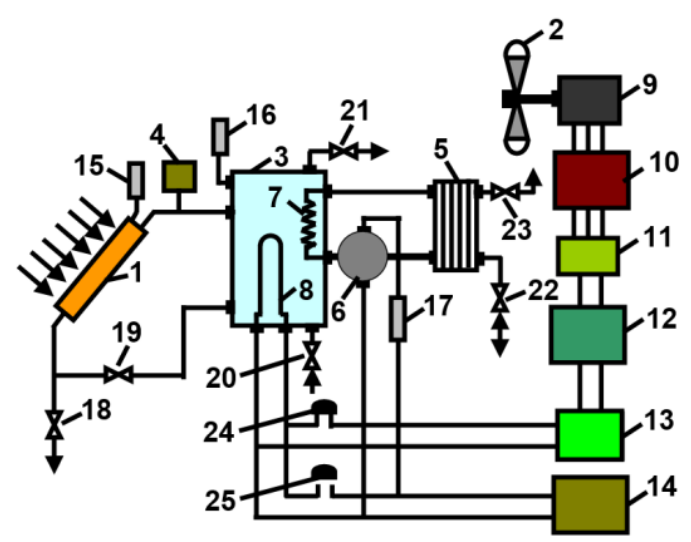

Figure 2. Simplified electric circuit diagram of the CSWPI.

The CSWPI consists of an FSC (1), a Wind Electric Machine (WEM) (2), a hot water tank (3), an expansion tank (4), a heating radiator (5), and a circulation pump (6) ensuring circulation of a heat transfer agent along the circuit. A snake heatexchanging unit (7) is installed inside the hot water tank (close to its lateral wall) and an electrical resistance heater (8) (at the centre of the tank's bottom wall). At the centre of the tank's bottom wall is located geared wind turbine (9). A voltage-reducing transformer (10) is connected to the power generator's outlet. The transformer's outlet is connected to the accumulator terminal (12) by the block for automatic control of charge and discharge processes (11). The accumulator terminal is also connected to the inlet of a phase inverter device (13). The option of using a centralised power network (14) in cases of calm weather conditions and during the hours of darkness is also foreseen. In cases where fully autonomous operation of the installation is required, a solarphotovoltaic power source may be utilised in place of a centralised power network. It should be remembered that such calm weather conditions seldom occur on the Apsheron Peninsula, especially in Baku City. For better control, the CSWPI is equipped with thermometers $(15,16)$, which receive signals from the thermocouples installed in the FSC's outlet and hot water tank (thermocouples are not shown in Figure 2). Start and shutdown of the circulating pump are directly controlled by the thermometer (17) with electrical contacts installed in the relevant place in a heated room. The installation is also equipped with regulating drain valves $18-23$. Valve 18 is considered for the discharge of a heat transfer agent in cases of long absence of inhabitants when freezing weather is anticipated, in order to prevent the bursting of FSC's pipes. As it is shown in Figure 2, Valve 19 is connected to the hot water tank according to a natural circulation scheme (in a thermo-syphon mode) and ensures the regulation of circulating heat transfer agent consumption, and by doing this, regulates the temperature regime of hot water. Valves 20 and 21 serve for filling the hot water tank and use of hot water by inhabitants, respectively. Valves 22 and 23 serve to fill the heating radiator (5) with a heat transfer agent (water also may be used as a heat transfer agent) and to eliminate any vapour locks (steam pockets). The electrical resistance heater (8) is connected to the inverter's outlet (13) and the centralised power network (14) by electrical switches 24 and 25 respectively.

\subsection{Operating principle of the experimental CSWPI}

The operating principle of the experimental CSWPI model is as follows: at the start, the surface of the FSC is turned towards the southwest and fixed at a required angle of inclination. Meanwhile, the hot water tank is placed at least $2-3 \mathrm{~m}$ above the FSC in order to enable natural circulation of a heat transfer agent. To start the operation, first, Valve 18 is closed and Valves 19-23 are opened. In this stage, the pipes of the FSC are flooded, the hot water tank is primed with cold water, and water begins to flow through Valves 21 and 23. At that moment, except for Valves 19 and 20, all other Valves $(21,22$ and 23) are closed. Sunrays passing through transparent glass surfaces of the FSC are absorbed by the heat absorbing plate, and this heats the plate. Some portion of the absorbed heat is transferred to the pipes that are directly connected to the plate. These pipes transfer this heat to the water circulating through them and the remaining heat is repelled toward the glass surface. The glass surface is not transparent to heat radiation and the repelled heat returns to the plate's surface and is absorbed by it. As a result, water flows in the FSC's pipes and the hot water tank. Later, the water that flows through Valve 19 is also heated up and provides additional heat to the hot water tank. If in winter it becomes necessary to protect the pipes of the FSC against freezing, Valves 18 and 21 should be opened simultaneously, while all other valves should be kept closed. Water is then drained from the FSC through Valve 18. Since no 
control signal from the contact thermometer is received by the circulating pump in summer, this pump remains idle and the heating radiator's circuit stays in the closed position. In winter, this circuit, receiving control signals from the contact thermometer, automatically connects to the system and the rooms in the house begin to receive heat.

\subsection{Analysis of the results obtained from the experiment}

However, studies of the CSWPI show that the FSC has played scarcely any role in heating individual households taken as study objects. This is not surprising if one remembers that on cloudy days, or during the night time hours of winter or other seasons, the FSC would not be capable of producing sufficient quantities of hot water for users without relying on additional accumulating systems. Thus, the task of providing consumers with an uninterrupted supply of hot water and heating is mainly fulfilled by a wind turbine. The use of wind turbines also offers the following advantages: the circulating pump does not need to be fed from the power network during winter, and since no home heating is required in summer, the majority of hot water needs are reserved by the FSC, and the energy accumulated in WEM may be utilised for other purposes. For example, though this study is mainly focused on the heating of individual households, it should be remembered that in summer they are badly in need of air conditioning. Upon filling the need for hot water, the remaining energy of a wind turbine may be directly supplied to fans and other electrical equipment installed in the house. The accumulator block (12) is connected to the wind turbine's outlet. Inhabitants may be fully supplied with hot water in the summer time day and night by the CSWPI on partly cloudy or cloudy days when the SRI intensity drops abruptly, or under windless conditions. Upon achieving a sufficient reserve of hot water (200-300 litres), the wind turbine may supply power to a fan in the experimental house during the hotter second half of the day and ensure an indoor temperature range of $20-22^{\circ} \mathrm{C}$ under outside temperatures of $35-40^{\circ} \mathrm{C}$.

There are a number of other advantages of wind turbine usage. During winter, there is no need to rely on the electric network to power the circulation pump. Since there is no need for heat provision during the summer season, all hot water supplies can be provided by the flat-plate solar collector. Energy produced by the wind turbine can be used for other purposes, such as refrigerators, electric lights, TVs, washing machines, vacuum cleaners, etc. In this regard, the present case discusses the heating of individual apartments, but in summer there is huge demand for the cooling of apartments, which is why the additional electricity produced by a wind turbine can be directed to electrical cooling equipment, providing sustainable cooling for residential buildings. In summer, people usually decide for themselves how to make use of electrical power produced by wind turbines.

At this time, except for electric lamps, which are not directly connected to the power grid, the remainder of household appliances are feeding phase-inverters. It is difficult for small wind turbines to directly connect to the grid-connected system; however, there is no such problem for large-scale wind turbines. If there is a sufficient hot water supply (200-300 L), WES can produce sufficient energy to cool a room to under $22^{\circ} \mathrm{C}$ when it is $35-40^{\circ} \mathrm{C}$ outside. In this case, the decline in the rooms' heating and cooling temperature is probably the same. That is why the installed equipment needs some amount of power to provide cooling in summer and heating in winter.

The FSC in the experimental CSWPI surface extends to $4 \mathrm{~m}^{2}$. The plates absorbing sunrays are equipped with a selective cover. The top surface of plates is covered with a single-layer of glass, while the bottom surface has a thermal coating, which reduces heat waste to a minimum.

\section{Information on equipment used in the experiment}

The wind turbine is a product of Yangzhou Shenzhou Wind-driven Generator Co., Ltd (SWG), a Chinese company. It is a 3-bladed, high-speed motor model SWG -E-2000, with a $3.2 \mathrm{~m}$ diameter rotor and rotor sweep area of $8.0 \mathrm{~m}^{2}$. Its specifications are as follows: nominal output power - $2000 \mathrm{~W}$; power generator type - assembled on the basis of a permanent magnet; generator $-\mathrm{Nd}-\mathrm{Fe}-\mathrm{B}$ model with 5 magnetic pole couples and a nominal output power of $48 \mathrm{~V}$; the wind's maximal operating speed $-18 \mathrm{~m} / \mathrm{s}$; the maximum permissible wind speed $-35 \mathrm{~m} / \mathrm{s}$; and the maximum rotation speed of a wind turbine's rotor spinning axis - $400 \mathrm{rpm}$. The wind turbine is connected to 4 RA12-260DG model gel accumulators. Their parameters are given in Table 1. In addition, an Xtender XTH 8000-48 model inverter with pure sinusoidal output voltage was used with following specifications: input voltage $-48 \mathrm{~V}$; optimal power $7.0 \mathrm{kWh}$; AC voltage $-220 / 180 \mathrm{~V} \pm 2 \%$; frequency $50-45 \mathrm{~Hz} \pm 0.05 \%$; and maximum efficiency $-96 \%$. The inverter stops automatically in cases of overloads and short circuits. It generates sound signals until the moment of automatic stoppage in cases of overheating. The inverter is equipped with an automation block, which regulates the accumulator charge and discharge processes.

Table 1. Constructive and energetic characteristics of gel battery type RA12-260DG combined exit of electric battery

\begin{tabular}{|c|c|c|c|c|c|c|c||}
\hline Type & $\begin{array}{c}\text { Capacity } \\
\text { A/hour }\end{array}$ & Size, $\mathbf{m m}$ & $\begin{array}{c}\text { General } \\
\text { height, } \\
\mathbf{m m}\end{array}$ & $\begin{array}{c}\text { Weight, } \\
\mathbf{k g}\end{array}$ & $\begin{array}{c}\text { Max inflow } \\
\text { movement, } \mathbf{A}\end{array}$ & $\begin{array}{c}\text { Max vacuum } \\
\text { movement, } \mathbf{A}\end{array}$ & $\begin{array}{c}\text { Internal } \\
\text { resistance, } \mathbf{\Omega}\end{array}$ \\
\hline $\begin{array}{c}\text { RA12- } \\
\text { 260DG }\end{array}$ & 260 & $520 \times 269 \times 203$ & 224 & 74.0 & 2600 & 52.0 & 8.0 \\
\hline
\end{tabular}


WEM has been installed on the property of the Radiobiology Center of the Institute of Radiation Problems of the Azerbaijan National Academy of Sciences. The small wind turbine is situated on a rooftop at a height of $12 \mathrm{~m}$ from the ground. In order to measure the wind speed, a Meteos (JDC) type anemometer was used. This anemometer also allows the measurement of air temperature. The device records 3 indicators in its light table: current wind speed on the upper line; maximum wind speed on the medium line; and average wind speed on the bottom line. In order to get precise results in the measurements, the data from the Azerbaijan Republic Department of Metrology were collected for 15-20 years at the height of $10^{-12} \mathrm{~m}$ with the same shading information. At the study site, the wind speed varies between $3-25 \mathrm{~m} / \mathrm{s}$ at that height. Figures 3 and 4 show the WEM's output power - wind speed and noise signals (when operating) - wind speed diagrams.

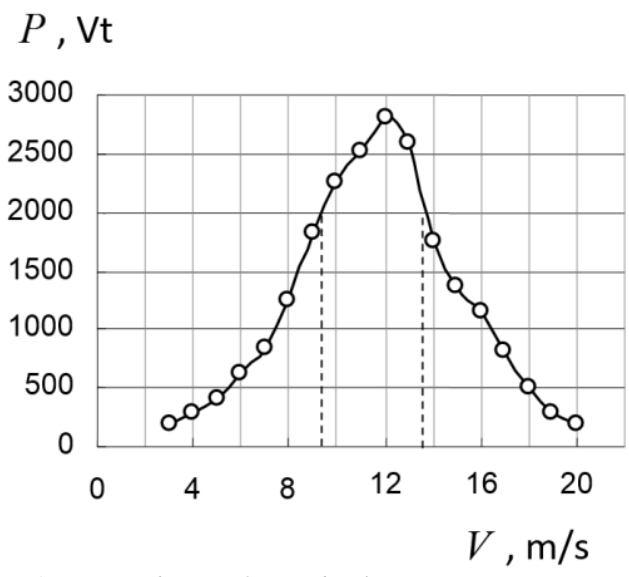

Figure 3. Graphics of wind plant power's exit power depending on wind speed.

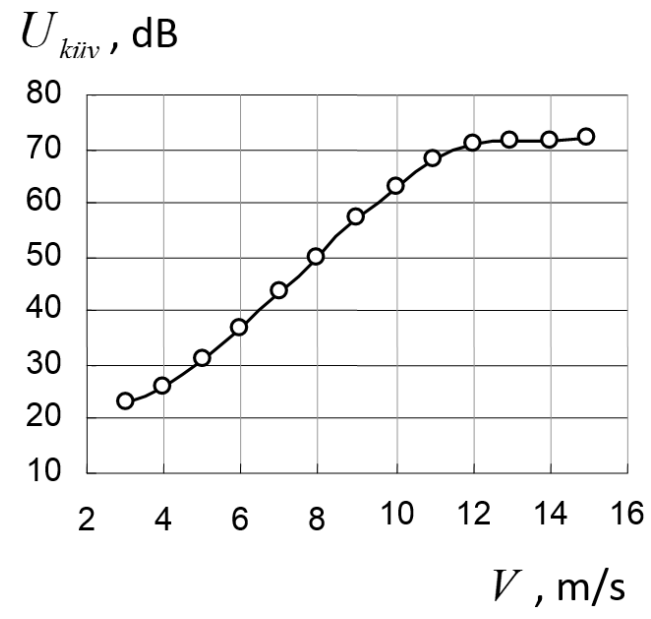

Figure 4. Graphics of noise sound level during wind power plant's operation depending on wind speed.

In order to assess the environmental impact of the wind turbine, the noise level was measured. For the purpose of measuring the sound level, an Italianproduced type HT 154, small-sized, digital apparatus was used. This apparatus was placed in special housing to absorb sound caused by wind and dimension interval changes ranging between 30-130 $\mathrm{dBA}$. The precision is $\pm 1.5 \mathrm{dBA}$, and the frequency ambit is $5-8 \mathrm{kHz}$. Dimensions were implemented every $2 \mathrm{~m}$ from a 1 to $20 \mathrm{~m}$ distance from the wind power plant ( 5 measurements were made), and then an average rating was made. As seen from the dimensions, the level of the sound signal created by the wind power plant when operating at maximum capacity is not significant for the human ear.

The selection of the accumulator battery type RA12-260DG in the apparatus is related to this battery's capacity. Secondly, it can work sustainably in the regime of both the buffer and deep inflowvacuum. Thirdly, its sustainability is longer than other accumulator battery types (about 10-15 years), and finally, they can work in a very wide temperature interval. Figure 5 shows graphics of accumulator battery capacity, which is dependent on temperature.

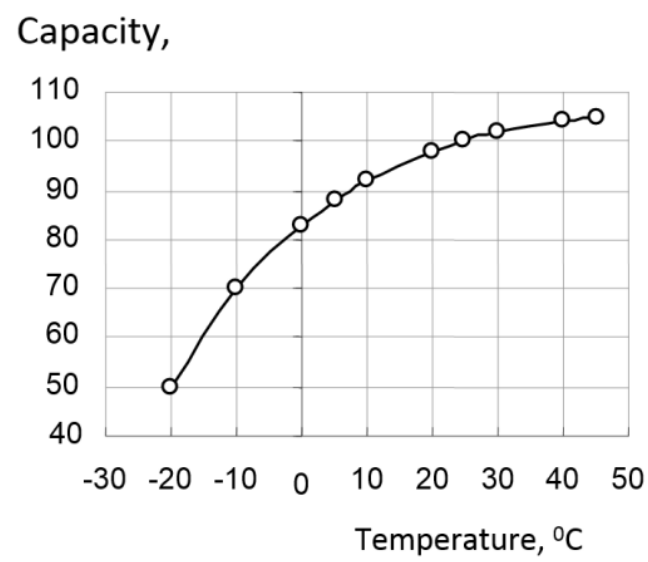

Figure 5. Graphics of gel accumulator's changing capacity type RA12 260DG depending on temperature.

\subsection{Wind regimes in meteorological stations on the Apsheron Peninsula}

There are 7 meteorological stations on the Apsheron Peninsula. In these areas, anemometers have a height of 10-12 meters and the flugers are in open areas. These stations include Apsheron Lighthouse, Pirallahi Island, stations in Baku, Zabrat, Mardakan, Mashtagha and the Sari Islands. In Figure 6 , the changing graphics of the average monthly speed of wind for Apsheron Lighthouse, Zabrat, Mashtagha and Baku stations are illustrated. When measurements were taken at these stations, real conditions were taken into consideration in much closer distances (to $2 \mathrm{~km}$ ) for the possibility of impediment that results in a shadow. The results of these measurements were corrected. Since most of the meteorological stations are surrounded by the Caspian Sea, these stations can be attributed to the higher classes for the degree of shading. But these stations are surrounded by settlements, villages, vegetation and hills, which can cause errors with changes in wind direction. These are not measurement errors but are related to statistical factors. We used references from the paper 'Prospects of Wind Energy Application in Azerbaijan' (Salamov et al., 2010). The experiments were conducted by the Hydrometeorology Investigation Bureau. We used the results from those data books. 


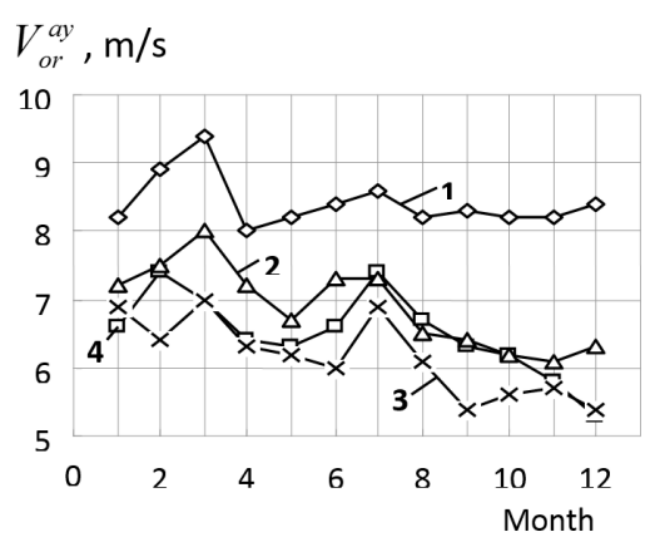

Figure 6. Graphics of changes in average monthly wind speed during a year at different locations on the Apsheron Peninsula: 1 -Apsheron Lighthouse; 2-Zabrat; 3-Mashtagha; 4-Baku.

The observations showed that the greatest annual average speed of wind at the meteorological stations on the Apsheron Peninsula was at Apsheron Lighthouse, and the least annual average speed of wind at the meteorological stations was at Sari Island (Salamov et al., 2010). But the annual average speed of wind at Sari Island is $6.2 \mathrm{~m} / \mathrm{s}$ at a height of $30 \mathrm{~m}$. This is a suitable regime for using a wind power plant that can be used in an individual form for energy production. However, considering the annual average wind speed, it would be incorrect to speak about the efficient use of a wind power plant in any district. For this, distribution characteristics should be learned during a year for the momentary wind speed for its different ranking of the annual average wind speed, as well as the amount of windless days and hours during a year. These issues were previously researched in detail for all of Azerbaijan (Salamov et al., 2010). Then, the parameters for Baku's climatic conditions were researched and the overall result was studied (Salamov et al., 2013). The results of measurements gathered at installed meteorological stations in the Mashataga settlement revealed that generally on the Apsheron Peninsula, as well as in Baku, the windless period (silence regime) of less than 12 hours captures $80 \%$ of the entire windless regime. The windless period, which continues up to 24 hours, captures $4-18 \%$ of the entire windless regime, while a 3-day windless regime reduces the capacity by only $1 \%$. However, research studies have shown that energetic silence of a more than 3-day duration period has not been observed at Mashtagha meteorological station in the last 5 years. The location where the wind's annual average speed is $8 \mathrm{~m} / \mathrm{s}$ for the number of days for different gradations of the momentary wind speed is given in Figure 7 (where $V_{a n i}-$ instantaneous wind speed).

\section{Number of days}

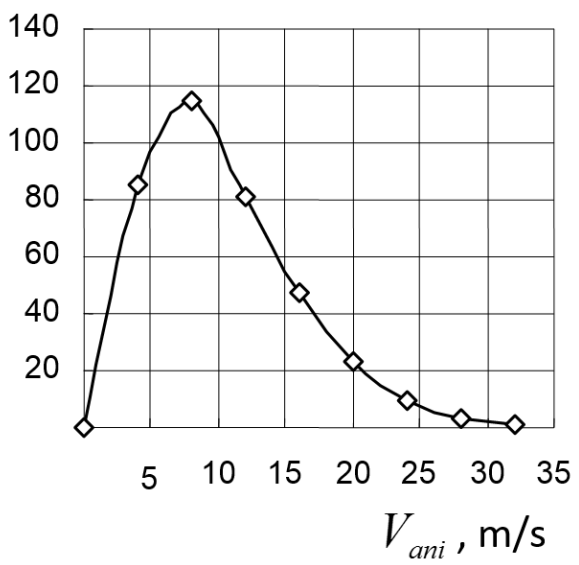

Figure 7. Frequency curve of instantaneous wind speed in the Apsheron Peninsula for the wind speed value of $8 \mathrm{~m} / \mathrm{s}$.

$V_{\text {ins }}<4-85 ; 4<V_{\text {ins }}<8$ - 114.6; $8<V_{\text {ins }}<12$ - 81; $12<V_{\text {ins }}<16-47.8 ; 16<V_{\text {ins }}<20-23.4 ; 20<V_{\text {ins }}<$ $24-9.1 ; 24<V_{i n s}<28-3 ; 28<V_{\text {ins }}<1.1$. Consequently, as it appears from the data above, on the Apsheron Peninsula, particularly with Baku City's climatic conditions, the number of days with the wind speed at which a wind turbine will be able to operate at nominal output power $\left(V_{a n i}>8 \mathrm{~m} / \mathrm{s}\right)$ is $365-80=$ 280 days. Thus, a single installation including both a wind turbine and an FSC may supply a family of 5 with uninterrupted hot water throughout the year, and with household heating for 8-9 months in a year, where hot water temperature will be $55-60^{\circ} \mathrm{C}$, while the CSWPI productivity will be 400 litres/day. In winter, maintaining the required indoor temperature by the CSWPI may present certain difficulties; therefore, in such cases, the centralised power network may need to be relied on an alternative energy source. On such days, an electrical heating element with the maximum required power of $1.5 \mathrm{~kW}$ and coated with an insulation layer may be employed as the heating element. This heating element, installed inside the hot water tank (hot water tank also playing the role of an accumulator), is connected to the wind turbine and the centralised power network by electric switches (24) and (25). Considering the minimum heat load and intended use, a single-circuit system based on natural circulation (thermo-syphon) of a heat transfer agent was used in the experimental model. At present, this choice has also been utilised with the aim of eliminating additional energy losses occurring due to the connection of the circulating pump to the circulation circuit of the hot water tank.

\subsection{Heat and hot water supply using flat solar collectors in $B$ and $C$ zones}

In addition to all of the above, we studied the possibility of providing a family of 5 living in areas with no expedient wind regime (zones B and C) (Salamov et al., 2010), using only solar energy (FSCs) even for WEMs with 10-15 $\mathrm{m}$ heights were insufficient in such zones for serving consumers' 
needs for hot water and heating. We accepted a person's daily hot water needs as being 80 litres. First, the quantity of daily average thermal load (TL) was calculated based on formulas from the reference literature. Thus, the daily heat load needs per person of a 5-member family was calculated using 80 litres water as a norm, and then this need was multiplied by the days of monthly water needed to achieve the result for heat load every month.

$$
Q_{\dot{I} Y}^{s u t}=a G_{p} \rho m N\left(t_{q . s u}-t_{s . s u}^{a y}\right)
$$

where, $a$ is hot water norm per person litres/s; $G_{p}$ - heat load of water, $\mathrm{W} /\left(\mathrm{kg}^{\circ} \mathrm{C}\right) ; \rho$ - water density, $\mathrm{kg} / \mathrm{L} ; m$ - number of family members; $N$ - days per month; $t_{q . s u} v$ ə $t_{s . s u}^{a y}-$ monthly temperature average of cold and hot water.

If we put the numbers in Equation (1) $(a=80 \mathrm{~L} / \mathrm{s}$; $G_{p}=1.16 \mathrm{~W} /\left(\mathrm{kg}^{\circ} \mathrm{C}\right) ; \rho=1 ; m=5 ; N=1 ; t_{\text {q.su }}=$ $50^{\circ} \mathrm{C} ;$ v $t_{\text {s.su }}^{a y}=15^{\circ} \mathrm{C}$ ), then we obtain the following results for heat load: $16.3 \mathrm{kWh}$ per day; $489 \mathrm{kWh}$ per 30-day month; $505.3 \mathrm{kWh}$ per 31-day month; and 460 kWh for February. Then, the heat load of cold water for Baku City was calculated (Kharchenko, 1991; Salamov and Abbasova, 2006). TL was calculated for the following parameters: temperature of water $15^{\circ} \mathrm{C}$, temperature of hot water $-50^{\circ} \mathrm{C}$, temperature of the heat transfer agent at the FSC output $t_{\text {h.tr.agent }}^{\text {outp }}=55^{\circ} \mathrm{C}$; and temperature of air - monthly average value for the zone. Temperature of water was taken as $15^{\circ} \mathrm{C}$, taking into account the annual water average in Baku City. The calculated values of daily, monthly and annual average TL are as follows: $Q^{d} T$. $=16.3 \mathrm{kWh}, Q_{T L}^{m}=496.1 \mathrm{kWh}$ and $Q^{a n} T L=5963.6$ kWh.

As it is known, using FSCs for a hot water supply requires optimal angular positioning of solar collectors' surfaces in relation to the horizon in order to ensure optimal daily, monthly and annual thermal loads. This angle is calculated as follows:

$$
\beta=\varphi+\delta
$$

where $\beta$ is the inclination angle of the FSC surface in relation to the horizon; $\varphi$ is the circle of the latitude angle (for the Apsheron Peninsula and Baku City, the value is taken as $40^{\circ} 24^{\prime}$ ); $\delta$ is the inclination angle of the vector (directed toward the sun at noon) in relation to the horizontal plane (also called 'solar declination' in reference literature), which has a positive value for the Northern hemisphere and negative value for the Southern hemisphere.

Figure 8 shows the annual variation of the solar declination angle's monthly average values. The average monthly optimal inclination angle of FSC surfaces was determined on the basis of Equation (2), which is based on the monthly average $\delta$ values provided in Table 2.

$$
\delta \text {, angle }
$$

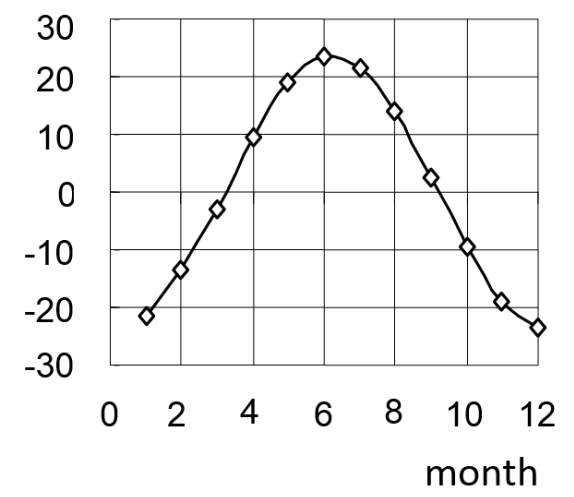

Figure 8. Annual variation of solar declination angle's monthly average values.

Testing and research work performed over a number of years have shown that even though FSCs have their own optimal inclination angle values for each day, direct connection of their structures to relevant utility lines (water, etc.) does not allow for daily angular adjustments and even the employment of automatic control systems does not prove their worth. In fact, changing the FSC surfaces' angles even during a month or only once in a season presents certain difficulties, and, therefore, they are usually fixed at some particular angular position, which may be considered the most optimal one throughout the year, while all heat- and energy-related calculations are performed for this single angle. In such cases, the solar declination angle in Equation (2) is taken to be equal to zero, which, according to Figure 8, roughly corresponds to the spring (March) and autumn (September) seasons.

Table 2. The average monthly optimal inclination angle of FSC under Baku City's climatic conditions.

\begin{tabular}{|c|c|c|c|c|c|c|c|c|c|c|c|c||}
\hline Months & I & II & III & IV & V & VI & VII & VIII & IX & X & XI & XII \\
\hline$\beta$, ang. degrees. & 61.22 & 53.78 & 42.80 & 30.79 & 21.55 & 17.35 & 19.32 & 26.75 & 38.52 & 50.23 & 59.51 & 63.45 \\
\hline
\end{tabular}

According to the reference literature, taking optimal inclination angles of FSC surfaces for the winter, spring/autumn and summer seasons ( $\beta=\varphi+15^{\circ}, \beta=\varphi$ and $\beta=\varphi-15^{\circ}$, respectively) is considered more feasible in connection with operation of FSC-based solar water heating units (SWHU). The average monthly value of SRI absorbed daily by $1 \mathrm{~m}^{2}$ of the surface is determined for these values of angles: $7^{\prime}, 8^{\prime}$, and $11^{\prime}$, respectively. In this case, the optimal inclination angles of FSC surfaces for the winter, spring/ autumn and summer seasons will be: $\beta_{W}=40^{\circ} 24^{\prime}+15^{\circ}=55^{\circ} 24^{\prime}, \quad \beta_{\text {sp-au }}=40^{\circ} 24^{\prime} \quad$ and $\beta_{\text {summ }}=40^{\circ} 24^{\prime}-15^{\circ}=25^{\circ} 24^{\prime}$, respectively. It is also important to note that when choosing between the above 3 cases for the annual average inclination angle of FSC surfaces, the latitude and longitude of the SWHUs' operation site, as well as the optimal orientation of the FSC toward the sun's trajectory (poles), should be taken into account. In order to determine the most feasible inclination angle for 
FSCs, we determined the energy and heat parameters, as well as monthly average values of its coefficient of efficiency. For this purpose, and in conformity with the study methodology, we determined average monthly values of SRI for $1 \mathrm{~m}^{2}$ of the inclined surface $\dot{I}_{\text {tot }}^{I S}$ based on analogous values for the horizontal surface $\dot{I}_{d i r}^{H S}$, specifically, 3 and 8. First, we determined monthly average values of relevant slope coefficients $\left(R_{\text {Inc. }}^{\text {mon }}=\dot{I}_{\text {tot }}^{I S} / \dot{I}_{\text {tot }}^{H S}\right)$, and then monthly average values of $\dot{I}_{\text {tot }}^{I S}$ were found. Based on the obtained results, the annual variation graphs were prepared. Figure 9 shows the annual variation of the monthly average values of daily direct $\left(\dot{I}_{\text {dir }}^{H S}\right)$, dispersed $\left(\dot{I}_{\text {disp }}^{H S}\right)$ and total $\left(\dot{I}_{\text {tot }}^{H S}\right)$ SRI for $1 \mathrm{~m}^{2}$ of the horizontal surface, while Figure 10 shows annual variation of the monthly average values of daily total $\left(\dot{I}_{t o t}^{H S}\right)$ SRI for $1 \mathrm{~m}^{2}$ of the inclined surface and $\beta_{\text {summ }}=25^{\circ} 24^{\prime}\left(\right.$ Curve 1), $\beta_{s p-a u}=40^{\circ} 24^{\prime}$ (Curve 2) and $\beta_{w}=55^{\circ} 24^{\prime}$ (Curve 1) values.

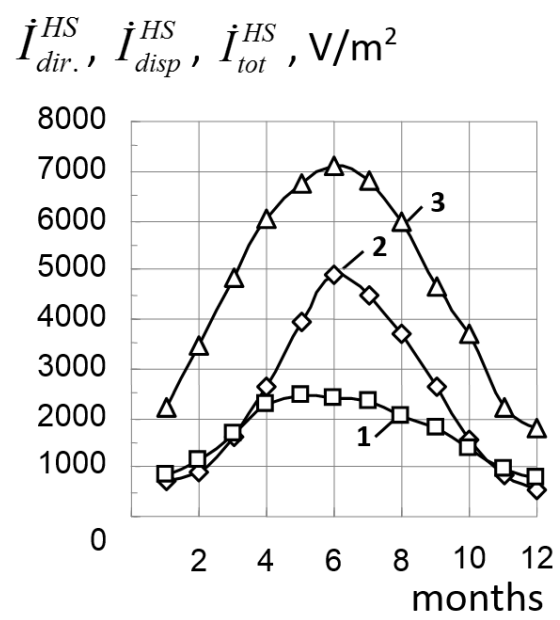

Figure 9. Annual variation of the monthly average values of daily direct $\left(\dot{I}_{\text {dir }}^{H S}\right)$, dispersed $\left(\dot{I}_{\text {disp }}^{H S}\right)$ and total ( $\left.\dot{I}_{\text {disp }}^{H S}\right)$ SRI for $1 \mathrm{~m}^{2}$ of the horizontal surface 1 $\dot{I}_{d i r}^{H S} ; 2-\dot{I}_{d i r}^{H S} ; 3-\dot{I}_{d i s p}^{H S}$.

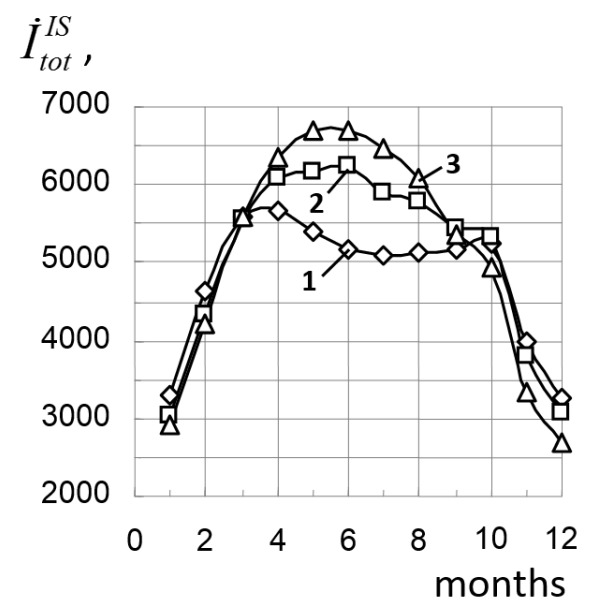

Figure 10. Annual variation of the monthly average values of daily total $\left(\dot{I}_{\text {disp }}^{H S}\right)$ SRI for $1 \mathrm{~m}^{2}$ of the inclined surface.

When comparing these 2 graphs, it becomes clear that even though the annual variation of monthly average values for $1 \mathrm{~m}^{2}$ in 3 cases showed similar behaviour (this is statistical data from Baku City),
Figure 10 shows that when FSC's optimal inclination angle is set for that of the summer optimal angle (Curve 3), the maximum value of SRI will be in summer and the minimum value in winter. Similarly, if one were to turn FSCs to the optimal inclination angle for winter, the maximum value of SRI would be in winter and the minimum value in summer. This comparison is not about SRI between winter and summer.

The comparison is the SRI monthly average between sloping surfaces and horizontal surfaces in $1 \mathrm{~m}^{2}$. On the one hand, this is a desirable option for the thermal load required in winter. It is greatly increased due to higher heat losses caused by multiple factors. In addition, the factor of utilisation of an additional energy resource diminishes.

The 3 optimal values for the FSC inclination angle, including the way the SRI for $1 \mathrm{~m}^{2}$ changes and assumes different values for winter and summer optimal angles, depend on the changing behaviour of a monthly average value of the slope coefficient $R_{\text {Inc. }}^{\text {mon }}$. Figure 11 shows annual variation of the slope coefficient $R_{\text {Inc. }}^{\text {mon }}$ for installation of an FSC at optimal angles for winter, spring/autumn and summer.

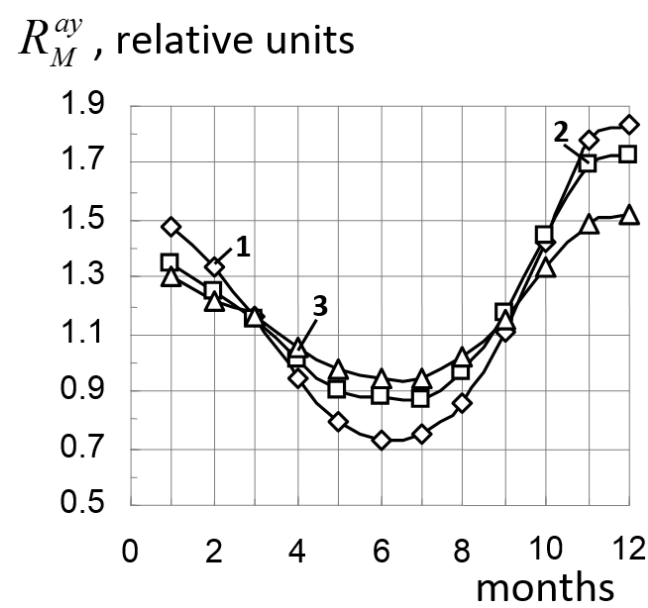

Figure 11. Annual variation of the average monthly value of the inclination angle. Curves 1, 2, and 3 represent FSC surface's inclination angles $55^{\circ} 24^{\prime}, 40^{\circ} 24^{\prime}$, and $25^{\circ} 24^{\prime}$, respectively.

The amount of solar energy falling on $1 \mathrm{~m}^{2}$ of the sloped FSC surface was calculated, such calculated values for $\beta_{w}==55^{\circ} 24^{\prime}, \beta_{s p-a u}=40^{\circ} 24^{\prime}$ and $\beta_{\text {summ }}=$ $25^{\circ} 24^{\prime}$ being $1764.5 \mathrm{~kW} /$ hour, $1846.5 \mathrm{~kW} /$ hour and $1864.9 \mathrm{~kW} /$ hour, respectively, while for the horizontal surface $\left(\beta=0^{\circ}\right)$ it amounted to $1691.6 \mathrm{kWh}$. The comparative analysis of the obtained data shows that the installation of an FSC at the angle that is optimal for the spring/ autumn period would be more feasible. Taking this into account, heat and energy calculations of SWHU in connection with compensation of daily thermal load required for supplying experimental house inhabitants with hot water during different months were made on the basis of the FSC inclination angle equal to the Baku City's circle of the latitude angle $\left(\beta_{s p-a u}=40^{\circ} 24^{\prime}\right)$.

Average monthly values of air temperature $\left(t_{\text {air }}^{\text {month }}\right)$, heat transfer agent's temperature at FSC entrance $\left(t_{\text {h.t.a. }}^{\text {ent }}\right)$ and cold water temperature $\left(t_{\text {co.w. }}^{\text {month }}\right)$ 
as well as SWHU's daily uninterrupted operation time $\left(t_{o p}^{\text {month }}\right)$ and overall surface area for ensuring the daily thermal load $S_{F S C}^{\text {month }}$ were also taken into account during calculations (annual variation of these parameters is shown in Figure 12 below).

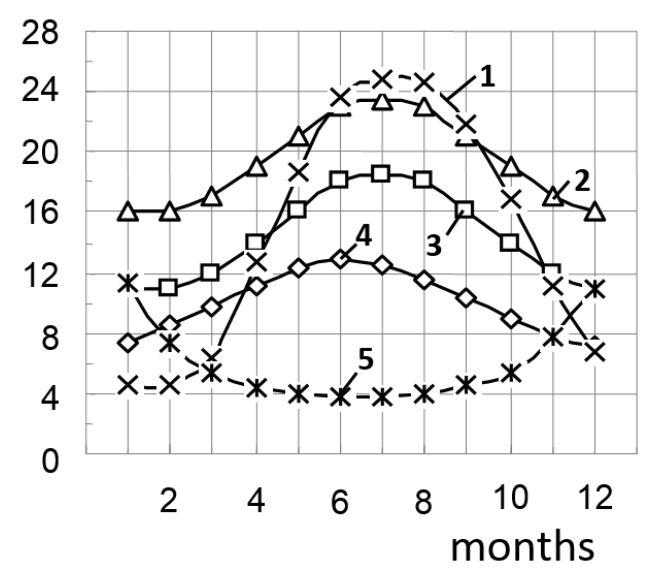

Figure 12. The average monthly values of air temperature $\left(t_{\text {air }}^{\text {month }}\right)$, heat transfer agent's temperature at FSC entrance ( $\left.t_{\text {h.t.a. }}^{\text {ent }}\right)$, cold water temperature $\left(t_{\text {co.w. }}^{\text {month }}\right), S W H U$ 's daily uninterrupted operation time ( $t_{o p}^{\text {month}}$ ) and overall surface area for ensuring the daily thermal load $S_{F S C}^{\text {month }}$ (curves 1, 2, 3, 4 and 5, respectively)

For the determination of optimal values of overall FSC surfaces, the average monthly values of daily absorbed SRI by $1 \mathrm{~m}^{2}$ of such surfaces $\dot{I}_{a b s}^{\text {day }}$ were calculated in the first instance, where the following assumptions were made: the reduced absorption capacity of FSC surface $-\theta=0.73$; reduced heat loss coefficient $-U_{h . l}=6 \mathrm{~W} / \mathrm{m}^{2}{ }^{\circ} \mathrm{C}$; and heat transfer agent's temperature at FSC outlet $-t_{\text {h.t.a. }}^{\text {ent }}=55^{\circ} \mathrm{C}$. Then, the monthly thermal load values $S_{F S C}^{\text {month }}$ required for supplying experimental house inhabitants with hot water during different months were determined along with the values of SRI absorbed by $1 \mathrm{~m}^{2}$ of the FSC surface during different months of the year $\dot{I}_{a b s}^{d a y}$ and the amount of the daily energy $Q_{e f f}^{\text {daily }}$. absorbed by an FSC and efficiently used. Figure 12 (Curve 5) shows the annual variation in optimal values of the FSC overall surface, while Figure 13 shows the annual variation of $\dot{I}_{a b s}^{\text {day }}$ and $Q_{e f f .}^{\text {daily }}$ parameters.

$$
\dot{I}_{\text {abs }}^{\text {day }} \mathrm{Vt} / \mathrm{m}^{2} ; Q_{\text {eff. }}^{\text {daily }}, \mathrm{kWh}
$$

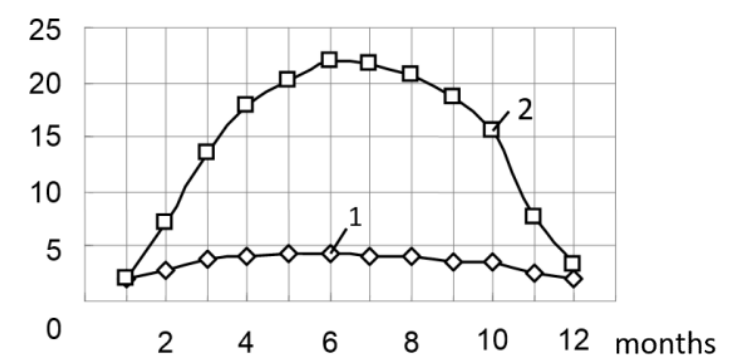

Figure 13. Annual variation graphics of daily absorbed SRI $\dot{I}_{\text {abs }}^{\text {day }}$ in $1 \mathrm{~m}^{2}$ of an FSC and effective use of solar energy $Q_{\text {eff. }}^{\text {daily }}$ by all the surface of an FSC: curves 1 and 2, respectively.
Further calculations revealed that if one were to choose FSC overall surfaces in accordance with the spring/autumn season requirements $\left(S_{F S C}^{O v} \approx 5 \mathrm{~m}^{2}\right.$ ), then, except for during winter months, users of an FSC would receive sufficient quantities of hot water, while in December, January, and February, the quantity of hot water produced daily would be 73,54 , and 52 litres, respectively. Therefore, an additional energy source should be utilised for an uninterrupted and sufficient supply of hot water. Such alternative sources may be those which run on natural gas or wind power. In cases of operation of the installation in places distant from centralised power and gas supply networks, such alternative sources may be photovoltaic power sources or WEMs. If one were to take FSC overall surfaces as equal to summer's optimal values $\left(\sim 4 \mathrm{~m}^{2}\right)$, SWHU would be capable of supplying consumers with 80 litres of hot water per person both in winter and spring/autumn months. However, this will require the use of additional energy sources, which have a negative impact on SWHU's economic feasibility. The average monthly values of the SWHU's coefficient of efficiency $\eta_{S W H U}^{\text {month }}$ as well as factors of utilisations $f_{A E S}^{\text {month }}$ of alternative energy sources and FSC $f_{F S C}^{\text {month }}$ were determined and relevant graphs were constructed on the basis of the obtained results (see Figure 14).

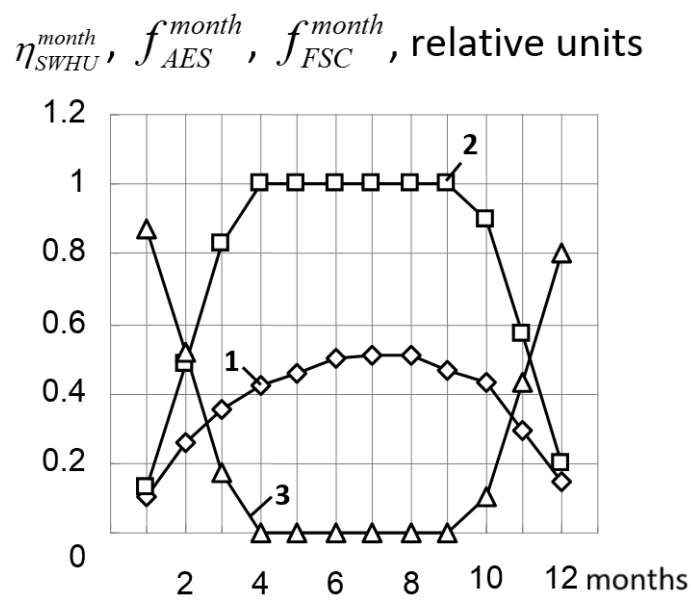

Figure 14. Annual variation of SWHU's coefficient of efficiency $\eta_{S W H U}^{\text {month }}$ as well as factors of utilisations $f_{A E S}^{\text {month }}$ of alternative energy sources and FSC $f_{F S C}^{\text {month }}$ : curves 1, 2, and 3, respectively.

Finally, monthly and yearly fuel savings for cases of alternative energy source utilisation (gas $E_{\text {gas }}^{\text {month }}$ and electricity $E_{\text {el. }}^{\text {month }}$ ) were determined. Figure 15 shows annual variation of these parameters. 


$$
E_{\text {gas }}^{\text {month }}, E_{\text {el. }}^{\text {month }}, \mathrm{kg} \text { of standard fuel }
$$

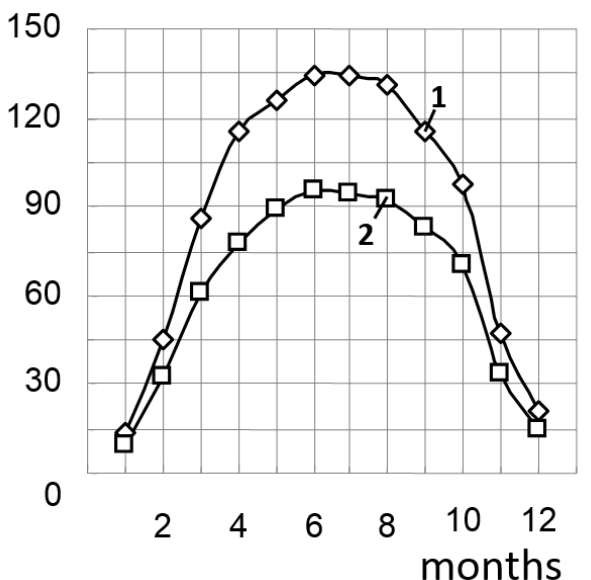

Figure 15. Annual variations of monthly and yearly amount of fuel savings for cases of alternative energy source utilisation (gas $E_{\text {gas }}^{\text {month }}$ and electricity

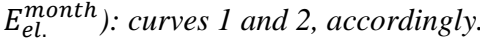

\section{Results and conclusion}

1. In this paper, damage to the atmosphere caused by conventional energy resources was reviewed. The usage perspective of low potential solar collectors was analysed. Since solar collectors cannot by themselves provide sufficient energy for heating and hot water during winter, the hybrid use of solar collectors and small wind turbines is considered to be practical.

2. It was determined that in Baku the number of sunny days equals 300 days and the number of sunshine hours are 3000 hours per year. During a year, sun radiation for a $1 \mathrm{~m}^{2}$ horizontal surface is 1900 $\mathrm{W} / \mathrm{m}^{2}$, and the maximum intensity of solar radiation is $950 \mathrm{~W} / \mathrm{m}^{2}$.The average annual value of that indicator is $200 \mathrm{~W} / \mathrm{m}^{2}$. Active solar radiation collection periods for winter and summer seasons are 4.8-7.8 and 7.2-12.5 hours, respectively. On the Apsheron Peninsula and along coastal areas of the Caspian Sea, there are $270-280$ windy days, and the average wind speed is $7-8 \mathrm{~m} / \mathrm{s}$, which in some places exceeds $10 \mathrm{~m} / \mathrm{s}$. In order to show the efficiency of wind energy, various graphs were illustrated and analysed.

3. The results of the measurements gathered at installed meteorological stations in the Mashataga settlement revealed that generally on the Apsheron Peninsula, as well as in Baku, the windless period (silence regime) of less than 12 hours captures $80 \%$ of the entire windless regime. The windless period, which continues up to 24 hours, captures $4-18 \%$ of the entire windless regime, while a 3 -day windless regime reduces the capacity by only $1 \%$. However, research studies have shown that energetic silence of a more than 3-day duration period has not been observed at Mashtagha meteorological station in the last 5 years. The location where the wind's annual average speed is $8 \mathrm{~m} / \mathrm{s}$ for the number of days for different gradations of the momentary wind speed is given: $V_{\text {ins }}<4-85$; $4<V_{\text {ins }}<8-114.6 ; 8<V_{\text {ins }}<12-81 ; 12<V_{\text {ins }}<$
$16-47.8 ; 16<V_{\text {ins }}<20-23.4 ; 20<V_{\text {ins }}<24-9.1$; $24<V_{\text {ins }}<28-3 ; 28<V_{\text {ins }}<1.1$, where $V_{\text {ins }}$ is instantaneous wind speed.

4. The subject area of research was a 5-person single family house in Baku. The possibility of providing that house with heat and hot water by using hybrid solar and wind energy was investigated. For this purpose, in the laboratory of Radiation Problems Institute, a CSWPI was established and that application was being tested for 2 years under Baku's climatic conditions. The testing revealed that the device was able to provide the family with hot water for the whole year and with heating for 8-9 months of the year (except for winter months). In order to obtain heat for the remaining months (winter months), additional energy sources were needed. For this purpose, a $1.5 \mathrm{~kW}$ maximum power consumption electric heater was sufficient. This device was powered by the electricity network. A photoelectric solar panel or a small wind turbine can also be added to make the system $100 \%$ renewable.

5. In the paper, the general view and the blocking scheme of a CSWPI were characterised and its working principles were explained in detail. Technical characteristics and the main components of an FSC and a small wind turbine were described. In particular, wind turbine exit power and noise levels are illustrated in the graphs in relation to the wind speed. The capacity changes for accumulating batteries in relation to temperature were depicted with graphs. It was determined that between the wind speeds of $9.5 \mathrm{~m} / \mathrm{s}$ and $13.5 \mathrm{~m} / \mathrm{s}$ a small wind turbine performs at its nominal power. In the conditions when the wind speed is lower than $9.5 \mathrm{~m} / \mathrm{s}$ or higher than $13.5 \mathrm{~m} / \mathrm{s}$, the power output of a wind turbine decreases. At the maximum noise level with the maximum wind conditions, the noise level does not exceed the nominal level for human health. The capacity of accumulators changes in relation to temperature. At temperatures between $0^{\circ} \mathrm{C}$ and $50^{\circ} \mathrm{C}$, the capacity increases to between $84 \%$ and $115 \%$, respectively. At temperatures lower than $-10^{\circ} \mathrm{C}$ and $-20^{\circ} \mathrm{C}$, the capacity decreases abruptly. However, these low temperatures are not observed in Baku. Thus, accumulating batteries lead to reserve energy for silent regimes without wind and still ensure that the demand for heating and hot water is met for some hours $(10-12)$. This is considered normal for the wind regime on the Apsheron Peninsula.

6. It was determined that in the summer season consumers are fully provided with hot water and there is no need for heating during that season. The energy generated from a small wind turbine remains unused for the intended purpose. Therefore, during summer, energy from a small wind turbine can be utilised for air conditioning and other domestic uses in electric appliances.

7. In the paper, the possibility of providing a 5person household with hot water and heating by using a flat solar collector was also investigated. The quantity of hot water needed per person was considered to be 80 litres daily and the monthly amount of heating for all family members was 
determined. The monthly quantity of solar radiation intensity for $1 \mathrm{~m}^{2}$ of a flat solar collector and daily quantity of SRI for the whole sloping surface were determined. This was done by measuring SRI for $1 \mathrm{~m}^{2}$ in different months and the data were obtained from data books. To this end, for transition from the horizontal surface to the slope surface, the first monthly numbers of inclined coefficients were determined. The coefficient changes during the year were depicted in the graphs of FSC's inclination angle changes during the winter, spring/autumn and summer seasons. Then, monthly numbers of effectively utilised heat energy absorbed by the surface of flat solar collectors were established. Taking into account the monthly amount of heat needed to supply hot water, the annual value of conventional fuel savings was identified. When identifying the amount of monthly savings for conventional fuel, natural gas and electricity costs as a source of additional energy, both electric heater and natural gas were taken into account. It was determined that the conventional fuel savings for gas and electric heater were $1061 \mathrm{~kg}$ and $749 \mathrm{~kg}$, respectively. It is a good indicator for application used individually. Monthly prices for conventional fuel savings are given in the form of a graph dependency. It is also used as an individual figure which illustrates a single power plant in a very good way

8. In order to assess the perspective of providing an experimental single family house with hot water and heating throughout the year, the calculation was conducted by taking into account the following: the energetic parameters of wind turbines and flat solar collectors; monthly and daily heating loads needed for heating and hot water; wind speed; environmental temperature and cold water temperature; and quantity changes for some other indicators. This is due to the fact that wind turbines and flat solar collectors are of an inherently complex nature. Experimentally, it is impossible to make a judgement about the heat-energy balance and other characteristics resulting from wind turbines and flat solar collectors. Even the data of the same month can vary significantly from year to year. That is why we took into consideration 20-year worth of data results in making our calculations.

9. The average monthly price of SWHU efficiency, FSC and an alternative source use ratio were determined. It was revealed that SWHU's maximum efficiency occurs in July and August (0.51) and the minimum cost is in January (0.1). The average annual cost of efficiency is 0.37 , the average annual value of the FSC use ratio is 0.758 , while the alternative source annual use ratio value is 0.242 . The average monthly price changes are depicted in the graphics. The results in terms of solar energy use for hot water and heating supplies show that in Azerbaijan it is significantly effective. In this sense, the energy from small wind turbines can be used effectively for the entire year. The prospects for solar and wind energy usage in Azerbaijan, as well as their use for heating and hot water supplies, were researched. In the paper, detailed information was provided about the potential of solar and wind energy on the Apsheron Peninsula.
10. According to the research, it can be concluded that in order to provide different consumers with hot water and heating supplies the usage of hybrid solar wind installations is justified both economically and environmentally. These installations are considered for individual usage and can be applied broadly to isolated areas, complex terrains, as well as for supplying hot water and heating to military installations. During summer months, heat consumption is minimal. The usage of small wind turbines enables the use of electricity for the needs of power processors (such as domestic air conditioning).

\section{References}

Abdelmoneym, A. (1988). Thermal modes of heat accumulators with a phase transition to solar heaters [Doctoral Dissertation of the candidate of technical sciences]. Moscow.

Bekman, U., Kleyn, S., \& Daffi, J. (1982) Raschet sistem solnechnogo teplosnabjenija [Calculation of Solar Heating Systems]. Moscow: Energoizdat.

Carbonell, D., Michel Y., Daniel, P., Elimar, F. (2014). Simulations of combined solar thermal and heat pump systems for domestic hot water and space heating. In Solar Heating and Cooling for Buildings and Industry (SHC 2013). Proceedings of the 2nd International Conference. Energy Procedia, 48, pp. 524-534. http://dx.doi.org/10.1016/j.egypro.2014.02.062

Hashimov, A., Salamov, O., Salmanova, F., \& Rzayev, P. (2012). Hot water and heating prospects for the use of alternative energy sources. Problems of power, 2, pp. 70-77.

Kharchenko, N. V. (1991). Individual Solar Applications. Energoatomizdat.

Mammadov, Q. \& Salamov, O. (2011). Hybrid system for hot water and heating supply Azerbaijan Republic Patent, № İ 0002 .

NREL (National Renewable Energy Laboratory). (2012). Low-Cost Solar Water Heating Research and Development Roadmap. National Renewable Energy Laboratory, NREL/TP-5500-54793.

Panjiyev, A. (2007). Prospects for the use of renewable energy sources in Turkmenistan. Alternative Energy and Ecology, 9(53), 65-69.

Polyanin, A. (1998). Guide to the exact solution of heat and mass transfer. Moscow: Energoizdat.

Salamov, O. \& Abbasova, F. (2006). Calculation of solar water heating system for hot water supply of the rural family. Alternative Energy and Ecology, 6, pp. 30-36.

Salamov, O. (2008). Automated Solar Application for heat and hot water supply. Azerbaijan Republic Patent, № I 0053.

Salamov, O. \& Garibov, A. (2009). Water heating system by solar energy. Azerbaijan Republic Patent, № İ 0085.

Salamov, O. \& Garibov, A. (2010). Solar Application for Hot Water Supply Azerbaijan Republic Patent, № İ 0031 .

Salamov, O., Mammadov, F., \& Samadova, U. (2010). Prospects of wind energy application in Azerbaijan. ISJAEE, 1(81), 132-144.

Salamov, O. \& Salmanova, F. (2010). Hot water and heating private houses from solar and wind power plants in different variants of matching them together. Alternative Energy and Ecology, 5(85), 125-126.

Salamov, O., Hashimov, A., \& Aliyev, F. (2013). Hot water and heating private houses from solar and wind power 
plants in different variants of matching them together. Alternative Energy and Ecology, 5(85), 125-126.

Salamov, O., Hashimov, A., \& Aliyev, F.(2013). Prospects for the use of solar energy in Azerbaijan. Alternative Energy and Ecology, 8, pp. 64-78.

Shershnev, V. \& Dudarev, N. (2006). The solar heating system. Construction engineering.

Sun \& Wind Energy. (2014). Booming market without subsidy, Vol. 3, pp. 34-35.

Ushakova, A. (1986). Combined solar installation to heat and cold of the experimental residential building of the Institute of Solar Energy. The test results. Ashkhabad: Turkmenniinti. 


\title{
Karšto vandens ruošimo ir šildymo nuosavuose namuose, naudojant hibridinị saulès ir vẻjo energijos ịrenginị, galimybės Apsherono ịlankoje, Azerbaidžano Respublikoje
}

\author{
Arzu Huseynov ${ }^{1}$, Elnur Abbasov ${ }^{1}$, Oktay Salamov² ir Firuze Salmanova ${ }^{2}$ \\ ${ }^{1}$ Aplinkos inžinerijos institutas, Kauno technologijos universitetas, Kaunas, Lietuva \\ ${ }^{2}$ Radiacijos problemos problemu institutas, Azerbaidžano Nacionalinė mokslu akademija, Baku, Azerbaidžanas
}

(gauta 2015 m. gegužès mèn.; priimta spaudai 2015 m. liepos mėn.)

Šiame tyrime analizuojamos aplinkos apsaugos problemos, atsirandančios naudojant tradicinius energijos išteklius elektros ir šiluminès energijai gaminti. Pateikiami ịprastinių energijos šaltinių pakeitimo ị vejjo ir saulès energiją naudojančias technologijas privalumai. Darbe buvo tyrinètos kombinuotos saulès ir vejjo energijos panaudojimo galimybès tiekti energiją vidutinei 5 asmenų šeimai. Eksperimentiniai rezultatai buvo gauti atlikus išsamius tyrimus vyraujančiomis aplinkos sąlygomis Baku. Azerbaidžano Nacionalinės mokslų akademijos Radiacijos problemų institute buvo suprojektuotos ir išvystytos saulès ir vëjo hibridinès šildymo ir karšto vandens ruošimo sistemos. Darbe taip pat buvo analizuojamos karšto vandens ruošimo galimybès 5 asmenu šeimai ištisus metus, naudojant tik saulès energiją, ir pateikti tokio įrenginio energijos balanso skaičiavimo rezultatai.

Raktiniai žodžiai: plokštieji saulès kolektoriai, vëjo jëgainè, hibridinis saulès ir vejjo ịrenginys, šalto vandens cisterna. 